AT - TADBIR

JURNAL ILMIAH MANAJEMEN

Homepage: ojs.uniska.ac.id/attadbir
AT-TADB/R

JURNAL ILMIAH MANAJEMEN

\title{
Perbedaan Persepsi Akuntan Publik Dan Non Publik Terhadap Kode Etik Akuntan Indonesia
}

\section{Adi Mintoro, Sonny Hersona}

Fakultas Ekonomi dan Bisnis, Universitas Singaperbangsa Karawang Jl. H.S Ronggowaluyo Telukjambe Timur, Karawang, Jawa Barat 41361 e-mail: adimintoro2015@gmail.com

\begin{abstract}
This study examines the differences in perceptions of public accountants and non-public accountants to the code of ethics of Indonesian accountants, in order to determine whether there are differences in perceptions between public accountants and non-public accountants to the code of ethics of Indonesian accountants. The sample used is 110 samples consisting of 55 respondents, 55 respondents, public accountants and non-public accountants in Jakarta. Methods of data analysis using statistical tests and paired difference test t test at the level of 0.05. The analysis and hypothesis testing that have been carried out show that there are differences in positive perceptions between Public Accountants and the Code of Ethics for Non-Public Accountants. The Indonesian Institute of Accountants, seen from the t-test results, can be stated that public and nonpublic accountants have a good appreciation and interpretation of the Code. Indonesian Accountant. In addition, from the results of hypothesis testing, there is no difference in perception between Public Accountants and Non-Public Accountants.
\end{abstract}

Keywords: Difference Perceptions, Public Accountant, Non Public Accountants, Indonesia Accounting Code of Conduct.

\begin{abstract}
Abstrak
Penelitian ini mengkaji perbedaan persepsi akuntan publik dan non akuntan publik terhadap kode etik akuntan Indonesia, guna mengetahui ada tidaknya perbedaan persepsi antara akuntan publik dan non akuntan publik terhadap kode etik akuntan Indonesia. Sampel yang digunakan sebanyak 110 sampel yang terdiri dari 55 responden 55 responden Akuntan Publik dan Non Akuntan Publik di Jakarta. Metode analisis data menggunakan uji statistik dan uji beda berpasangan uji t pada taraf 0,05. Analisis dan pengujian hipotesis yang telah dilakukan diperoleh hasil bahwa terdapat perbedaan persepsi positif antara Akuntan Publik dengan Kode Etik Non Akuntan Publik Ikatan Akuntan Indonesia dilihat dari hasil uji-t dapat dinyatakan bahwa akuntan publik dan non publik memiliki apresiasi dan interpretasi serta pemahaman yang baik terhadap Kode Akuntan Indonesia. Selain itu, dari hasil pengujian hipotesis tidak terdapat perbedaan persepsi antara Akuntan Publik dan Non Akuntan Publik.
\end{abstract}

Kata kunci: Perbedaan Persepsi, Akuntan Publik, Akuntan Non Publik, Kode Etik Akuntansi Indonesia. 


\section{PENDAHULUAN}

Seiring dengan meningkatnya kompetisi dan globalisasi, setiap profesi dituntut untuk bekerja secara profesional. Kemampuan dan keahlian khusus yang dimiliki oleh suatu profesi adalah suatu keharusan agar profesi tersebut mampu bersaing di dunia usaha sekarang ini. Selain keahlian dan kemampuan khusus yang dimiliki oleh suatu profesi, dalam menjalankan suatu profesi juga dikenal adanya kode etika profesi.

Dengan adanya etika profesi maka setiap profesi memiliki aturan-aturan khusus yang harus ditaati oleh pihak yang menjalankan profesi tersebut. Etika Profesi diperlukan agar apa yang dilakukan oleh suatu profesi tidak melanggar batas-batas tertentu yang dapat merugikan suatu pribadi atau masyarakat luas. Etika tersebut akan memberi batasan-batasan mengenai apa yang harus dilakukan dan apa yang harus dihindari oleh suatu profesi.

Sampai saat ini, kredibilitas akuntan publik masih menjadi pertanyaan bagi masyarakat. Menurut hemat penulis telah terjadi krisis kepercayaan masyarakat terhadap profesi akuntan publik. Masyarakat memandang akuntan publik bukan lagi sebagai pihak yang dapat bersikap objektif dalam memberikan jasanya, karena akuntan dinilai berpeluang besar untuk mengadakan persekongkolan dengan manajemen perusahaan atau pihak tertentu.

Masalah ini berkaitan erat dengan persepsi akuntan terhadap kode etik itu sendiri. Menurut hemat penulis perlu dilakukan penelitian untuk mengkaji persepsi anggota profesi terhadap kode etik. Dengan melakukan penelitian, persepsi akuntan publik terhadap kode etik dapat diungkapkan sehingga memberi masukan yang aktual agar dapat diambil langkah-langkah yang tepat terutama bagi akuntan publik demi keberadaan profesi dan peningkatan citra profesi yang baik.

Penelitian hanya ditujukan kepada akuntan publik dan non publik di wilayah Jakarta.
Adapun pemilihan responden akuntan publik diambil dari KAP Persekutuan dengan jumlah Akuntan Publik lebih dari 10 (Sepuluh) orang. Sedangkan untuk Akuntan Non Publik Penulis memilih profesi Dosen untuk kampus yang memiliki program studi Magister.

Penulis menggunakan beberapa sumber antara lain dari Daftar Anggota IAI-SAP yang diterbitkan oleh Ikatan Akuntan IndonesiaSeksi Akuntan Publik, dan buku petunjuk telepon dan internet untuk mencari alamat akuntan yang menjadi sampel penelitian. Aspek yang diteliti adalah menyangkut bidang auditing yaitu mengenai pelaksanaan tugas profesional oleh akuntan publik maupun akuntan non-publik yang dikaitkan dengan kode etik terutama dalam persepsi terhadap kode etik bagi pelaksanaan tugas profesi sehari-hari.

Tujuan penelitian ini untuk menguji secara empiris apakah akuntan publik dan non publik memiliki persepsi yang positif terhadap kode etik akuntan publik dan untuk mengukur variabel atas proxy atau representasi dari persepsi akuntan publik dan non publik dari tanggung jawab profesi, kepentingan publik dan kerahasiaan apakah berpengaruh terhadap opini yang diberikan, serta untuk menguji secara empiris apakah terdapat perbedaan persepsi terhadap kode etik antara kelompok akuntan publik dan akuntan non-publik.

Penelitian ini diharapkan dapat memberikan manfaat dalam memberikan bukti deskriptif tentang persepsi akuntan terhadap kode etik. Di samping itu juga memberikan masukan dalam pelaksanaan Kode Etik Akuntan Indonesia. Pelaksanaan kode etik diharapkan dapat mencerminkan citra profesi yang tinggi dalam pelaksanaan tugas-tugas profesional sehingga mendorong perkembangan profesi di masa yang akan datang. 


\section{KAJIAN PUSTAKA}

Berdasarkan uraian hasil penelitian sebelumnya, pada penelitian yang dilakukan terdapat perbedaan dan persamaan. Pada penelitan sebelumnya mengkaji perbedaan persepsi kelompok akuntan, sedangkan penelitian yang dilakukan hanya pada kelompok akuntan publik. Persamaannya pada persepsinya terhadap kode etik profesi. Perbedaan lainnya adalah bahwa pada penelitian yang dilakukan mengkaji bagaimana pengaruh persepsi kode etik terhadap opini yang diberikan oleh akuntan publik.

\section{Persepsi Etika Profesi Akuntan}

Pengertian persepsi adalah proses memahami lingkungan, yang meliputi suatu objek, orang, tanda atau tanda, yang meliputi proses kognitif (kognisi). Proses kognitif adalah proses di mana seseorang memberi makna melalui interpretasi terhadap rangsangan (stimuli) yang muncul dari objek, orang, atau tanda tertentu. Dengan kata lain, persepsi melibatkan penerimaan, pengorganisasian, dan interpretasi rangsangan yang diatur untuk mempengaruhi perilaku dan membentuk hubungan. Hal ini karena persepsi melibatkan interpretasi individu terhadap objek tertentu, dan ketika melihat objek yang sama, setiap objek memiliki persepsi yang berbeda (Gibson et al., 1996).

Arti kata etika dalam terjemahan dari kata latin "ethics" berarti filsafat moral. Pedoman untuk memperbaiki perilaku dalam hal budaya, moralitas dan agama. Sedangkan menurut Keraf (1998), etika secara harafiah berasal dari kata Yunani ethos (jamak: ta etha). Ini memiliki arti yang sama dengan moralitas: kebiasaan baik.

Etika akuntan Indonesia diatur oleh Kode Etik Akuntan Indonesia. Di sisi lain, Kode Etik ini mengikat anggota IAI dan dapat digunakan oleh akuntan lain yang bukan atau bukan anggota IAI.
Di samping itu. Kode Etik Akuntan Indonesia yang baru dibagi menjadi tiga bagian (risalah rapat ke-8, 1998). 1. Kode Etik Umum. Etika Profesi Terdiri dari delapan prinsip etika profesi, yang merupakan landasan perilaku, memberikan kerangka dasar bagi Kode Etik dan mengatur pemberian layanan profesional oleh anggota. Ini termasuk tanggung jawab profesional, kepentingan publik, kejujuran, objektivitas, kompetensi dan kebijaksanaan profesional, kerahasiaan, perilaku profesional dan standar teknis. 2. Kode etik akuntan departemen. Kode etik akuntan departemen disetujui oleh rapat anggota departemen dan mengikat semua anggota departemen terkait. 3. Interpretasi Kode Etik Akuntansi. Penafsiran Kode Etik Akuntansi Cabang merupakan pedoman penerapan Kode Etik Akuntansi Cabang. 4. Pernyataan Etika Profesi yang berlaku saat ini dapat digunakan sebagai interpretasi dan/atau kode etik sampai dengan dikeluarkannya aturan dan interpretasi baru untuk menggantikannya.

Di Indonesia, kepatuhan terhadap Kode Etik setidaknya dilakukan oleh enam unit organisasi: Kantor Akuntan Bersertifikat, Unit Peer Review Unit Akuntan Bersertifikat - IAI, dan Dewan Pengawas Divisi Profesi Akuntan Bersertifikat - IAI. , Dewan Pertimbangan Profesi IAI di bawah Kementerian Keuangan Republik Indonesia dan BPKP. Selain enam unit organisasi di atas, anggota dan pengurus KAP diharapkan mampu mengawal Kode Etik itu sendiri. Hal ini tercermin dalam kata-kata paragraf 1 ayat 2 Kode Etik Akuntan Indonesia.

"Setiap anggota harus selalu menjaga integritas dan objektivitas dalam menjalankan tugasnya. Dengan tetap menjaga integritas, ia bertindak jujur, tegas dan tanpa kepura-puraan. Objektivitas. Dengan mendukung, ia bertindak adil tanpa terpengaruh oleh tekanan/tuntutan tertentu/kepentingan pribadi"

pihak 
Tabel 1. Ikhtisar Penelitian Terdahulu

\begin{tabular}{|c|c|c|c|c|}
\hline No & $\begin{array}{c}\text { Nama } \\
\text { Peneliti }\end{array}$ & Tahun & Operasional Variabel & Hasil Penelitian \\
\hline 1. & Aristyawan & 2010 & $\begin{array}{l}\text { 1. Kode etik IAI } \\
\text { 2. Mahasiswa PPAk } \\
\text { 3. Akuntan Publik } \\
\end{array}$ & $\begin{array}{l}\text { Terdapat pengaruh persepsi mahasiswa } \\
\text { akuntan PPAk dan akuntan publik } \\
\text { terhadap kode etik akuntan }\end{array}$ \\
\hline 2. & Sartika & 2006 & $\begin{array}{l}\text { 1. Kode etik } \\
\text { 2. Dosen akuntansi } \\
\text { 3. Mahasiswa } \\
\quad \text { akuntansi } \\
\end{array}$ & $\begin{array}{l}\text { Terdapat perbedaan yang signifikan } \\
\text { antara persepsi Dosen akuntansi dan } \\
\text { mahasiswa akuntansi terhadap kode } \\
\text { etik akuntan }\end{array}$ \\
\hline 3. & Yusriani & 2005 & $\begin{array}{l}\text { 1. Kode etik IAI } \\
\text { 2. Dosen Akuntansi } \\
\text { 3. Mahasiswa } \\
\text { akuntansi }\end{array}$ & $\begin{array}{l}\text { Tidak terdapat perbedaan persepsi yang } \\
\text { signifikan antara kelompok akuntan } \\
\text { pendidik dengan akuntan publik }\end{array}$ \\
\hline 4. & Syva & 2006 & $\begin{array}{l}\text { 1. Kode etik IAI } \\
\text { 2. Akuntan Publik } \\
\text { 3. Akuntan Non Publik }\end{array}$ & $\begin{array}{l}\text { Tidak memiliki persepsi yang positif } \\
\text { terhadap kode etik dan tidak terdapat } \\
\text { perbedaan persepsi yang signifikan } \\
\text { antara kelompok akuntan publik dan } \\
\text { non publik terhadap kode etik akuntan } \\
\text { Indonesia. }\end{array}$ \\
\hline 5. & $\begin{array}{l}\text { Murtanto } \\
\text { dan Marini }\end{array}$ & 2003 & $\begin{array}{l}\text { 1. Kode Etik IAI } \\
\text { 2. Akuntan Pria dan } \\
\text { Akuntan Wanita } \\
\text { 3. Mahasiswa dan } \\
\text { Mahasiswi }\end{array}$ & $\begin{array}{l}\text { Tidak terdapat perbedaan signifikan } \\
\text { antara persepsi pria dan wanita untuk } \\
\text { akuntan dan mahasiswa akuntansi } \\
\text { terhadap etika profesi akuntan. }\end{array}$ \\
\hline
\end{tabular}

\section{Kerangka Teoritis}

Profesi Akuntan Publik merupakan profesi yang menyediakan jasa kepercayaan yang penting bagi masyarakat. Oleh karena itu, tindakan profesi yang tidak bertanggungjawab dapat merusak kepercayaan masyarakat terhadap profesi tersebut. Kode etik digunakan sebagai sarana yang menjadi dasar kepercayaan masyarakat terhadap kualitas atau mutu jasa yang diberikan oleh profesi akuntan tanpa memandang siapa individu yang melaksanakannya. Dalam hal ini kompetensi dan independensi merupakan bagian dari Standar Auditing dan juga termasuk dalam Aturan Etika Akuntan Publik. Kompetensi berkaitan dengan kemampuan, keahlian dan pengalaman dari auditor. Sedangkan independensi adalah sikap auditor yang jujur, bebas, tidak memihak dan tidak mudah dipengaruhi. Penelitian ini disusun dari beberapa penelitian terdahulu yang ditunjukkan pada tabel 1 .

\section{Pengembangan Hipotesis}

Berdasarkan tujuan dan masalah yang diteliti dan yang digambarkan dalam model kerangka penelitian, maka hipotesis penelitian sebagai berikut:

Hipotesis : Terdapat perbedaan persepsi antara akuntan publik dengan akuntan non publik terhadap kode etik akuntan Indonesia. 


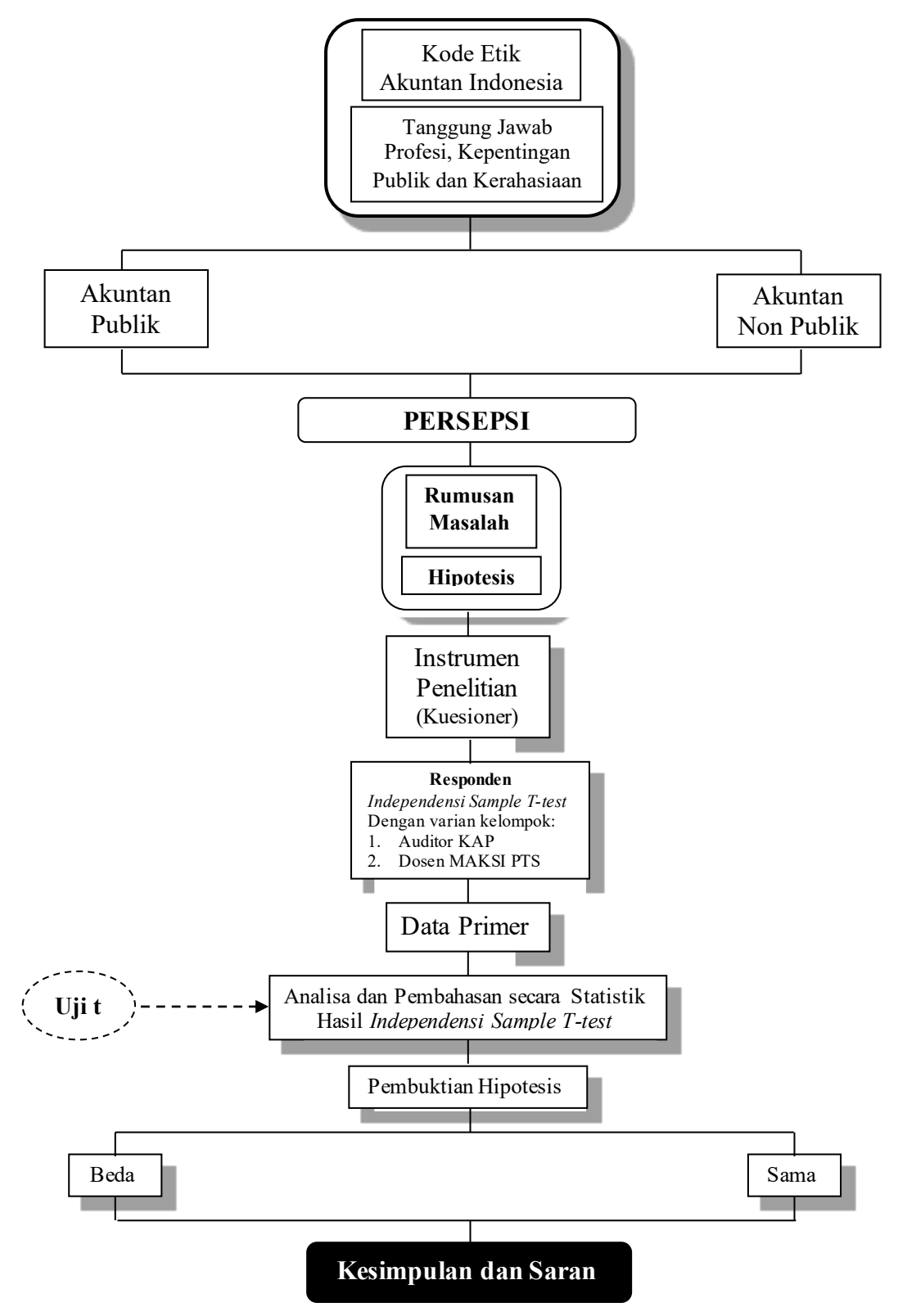

Gambar 1. Alur pikir penelitian

\section{METODE PENELITIAN}

\section{Jenis Penelitian}

Penelitian yang dilakukan adalah jenis penelitian kuantitatif, Tipe penelitian ini adalah penelitian eksploratori deskriptif. Menurut Cooper (1997) menyebutkan bahwa tujuan dari studi deskriptif adalah untuk mempelajari aspek siapa, apa dan bagaimana dari suatu sistematis. Selanjutnya data dianalisis dan diinterprestasikan secara deskriptif yang memaparkan situasi atau peristiwa yang terjadi saat ini agar diperoleh garmbaran tentang masalah yang diteliti. Menurut Soendari (2012), menyatakan yang dimaksud penelitian deskriptif yaitu menggambarkan suatu bentuk hubungan kausal antara variabel-variabel yang diteliti ditunjukkan dengan angka koefisien korelasi.

\section{Lokasi dan Waktu Penelitian}

Lokasi penelitian dilakukan di Jakarta dengan mengambil data dari berbagai sumber baik dari literatur maupun internet sehingga peniliti berdasarkan konsultasi dengan dosen pembimbing mengambil lokasi di Jakarta dengan sepsifikasi untuk lokasi Kantor Akuntan Publik (KAP) Persekutuan dengan jumlah AP lebih dari 10 orang dan untuk 
lokasi Kampus diambil dengan kampus yang telah mempunya program Magister Akuntansi di wilayah Jakarta. Sedangkan waktu penelitian ini dilaksanakan pada tahun 2019 seperti sudah dijelaskan sebelumnya diatas yaitu Dimensi waktu penelitian ini adalah cross sectional yang berarti penelitian hanya dilakukan sekali yaitu pada tahun 2019.

\section{Populasi dan Sampel}

Populasi dalam penelitian ini adalah Kantor Akuntan Publik dengan jumlah Akuntan Publik lebih dari 10 (Sepuluh) dan Perguruan Tinggi Swasta yang memiliki program Pasca Sarjana Magister Akuntansi yang relatif besar berada di wilayah Jakarta.

Cara penentuan sampel dengan metode purposive sampling yaitu sampel penelitian dari populasi yang memenuhi kriteria tertentu sesuai dengan yang dikehendaki oleh penulis (judgement). Kriteria penentuan sampel bertujuan untuk menghindari adanya misspesifikasi yang dapat mempengaruhi hasil analisis. Misalnya responden ditentukan pada anggota yang sudah berdinas di KAP dan Non KAP tersebut minimal 1 tahun, hal tersebut dilakukan agar kuesioner dapat dijawab sesuai dengan harapan atau tujuan penelitian, melalui variabel-variabel yang diteliti.

Setelah diketahui jumlah unit populasi, selanjutnya dilakukan penentuan besarnya jumlah/ukuran sampel dengan perhitungan rumus Slovin, sebagai berikut:

$$
\begin{gathered}
n=\frac{N}{1+N(e)^{2}} \\
n=\frac{150}{1+150(0,05)^{2}} \\
n=109.09 \text { (dibulatkan menjadi 110) }
\end{gathered}
$$

$\mathrm{n}=$ sampel; $\mathrm{N}=$ populasi; $\mathrm{e}=\%$ kesalahan (presisi; $=5 \%$ )
Berdasarkan hasil perhitungan ukuran sampel tersebut, maka diperoleh jumlah sampel penelitian sebanyak 110 (pembulatan) data atau responden. Data dalam penelitian ini dikumpulkan melalui survey dengan mengisi kuestioner yang dikirimkan kepada responden, karena keterbatasan waktu dan biaya serta pengembalian kuestioner yang memenuhi syarat dalm arti kembali yang lengkap (valid) yaitu sejumlah 55 responden dari Akuntan Publik (KAP) dan 55 responden dari Non Akuntan Publik (Dosen yang berpfofesi sebagai Akuntan Pendidik).

\section{Teknik Pengumpulan Data}

Data dari penelitian ini merupakan data primer yang dikumpulkan dengan teknik observasi, kuesioner, dan dokumentasi. Data sekunder juga diperoleh berupa profil perusahaan, sejarah perusahaan dan laporan perkembangan pelanggan/konsumen.

\section{Skala Pengukuran Variabel}

Data utama yang digunakan dalam analisis diperoleh dari jawaban responden melalui kuesioner (bentuk tertutup), yaitu responden memilih alternatif jawaban yang sudah tersedia disusun atas kesetujuan responden memberikan tanggan dengan 5 pilihan jawaban, yang terdiri dari Sangat Tidak Setuju (STS) diberi nilai 1 sampai dengan Sangat Setuju (SS) diberi nilai 5.

\section{Instrumen Penelitian}

Penelitian ini merupakan penelitian empirik unutk menguji hipotesis yang diajukan, variabel yang diteliti adalah persepsi akuntan terhadap kode etik. Unutk mengukur variabel tersebut dilakukan penelitian dengan menggunakan motede kuesioner tipe tertutup. Daftar kuesioner berisi 3 (tiga) bagian yaitu: bagian pertama atau A berisi pertanyaan umum yang meliputi identifikasi 
reponden; badian kedua atau $\mathrm{B}$ berisi pertanyaan yang di susun sedemikian rupa sehingga dapat mencerminkan persepsi akuntan terhadap kode etik; dan bagian ketiga atau $\mathrm{C}$ berisi pertanyaan mengehai persepsi terhadap kode etik dan pengaruhnya terhadap opini yang diberikan. Kisi-kisi kuesioner yang disusun sebagai berikut:

Tabel 2. Persepsi Akuntan Publik Dan Non Publik Terhadap Kode Etik

\begin{tabular}{|l|l|}
\hline \multicolumn{1}{|c|}{ Nomor Penyataan } & \multicolumn{1}{c|}{ Item Kode Etik } \\
\hline $1 \mathrm{a}, 1 \mathrm{~b}$ & Bagian Pendahuluan \\
\hline $2 \mathrm{a}, 2 \mathrm{~b}$ dan 3 & Bab I Pasal 1 (1) \& 1 (2) \\
\hline $4 \mathrm{a}, 4 \mathrm{~b}, 4 \mathrm{c}, 4 \mathrm{~d}$ & Bab II Pasal 2 \\
\hline 5 & Bab III Pasal 5 \\
\hline $6 \mathrm{a}, 6 \mathrm{~b}$ & Bab II Pasal 3 \\
\hline $7 \mathrm{a}$ & Bab IV Pasal 6 (3) \\
\hline $7 \mathrm{~b}$ & Bab IV Pasal 6 (4) \\
\hline $8 \mathrm{a}, 8 \mathrm{~b}$ & Bab III Pasal 4 \\
\hline 9,11 & Bab IV Pasal 6 (1) \\
\hline 10,12 & Bab IV Pasal 6 (5) \\
\hline $13 \mathrm{a}, 13 \mathrm{~b}$ & Bab IV Pasal 6 (6) \\
\hline $14 \mathrm{a}, 14 \mathrm{~b}$ & Bab IV Pasal 6 (7) \\
\hline $15,16,17,18$ & Bab IV Pasal 6 (9) \\
\hline 19,20 & Bab IV Pasal 6 (10) \\
\hline $21 \mathrm{a}, 21 \mathrm{~b}$ & Bab V Pasal 7 (2) \\
\hline 22 & Bab V Pasal 7 (3) \\
\hline 23,24 & Bab V Pasal 7 (4) \\
\hline
\end{tabular}

Sumber: Siek Yen, 2003

Tabel 3. Instrumen Variabel Terikat Opini Akuntan Publik dan Non Publik

\begin{tabular}{|c|c|c|c|c|}
\hline No & $\begin{array}{l}\text { Dimensi Opini } \\
\text { Akuntan Publik }\end{array}$ & Indikator & Validitas & Reliabilitas \\
\hline \multirow[t]{2}{*}{1.} & \multirow[t]{2}{*}{ Wajar tanpa syarat } & $\begin{array}{ll}\text { Penilaian yang dapat } \\
\text { dipertanggung jawabkan }\end{array}$ & 0,798 & \multirow[t]{2}{*}{0,777} \\
\hline & & Penilaian sudah sesuai kode etik & 0,899 & \\
\hline \multirow[t]{2}{*}{2.} & \multirow{2}{*}{$\begin{array}{l}\text { Wajar dengan } \\
\text { pengecualian }\end{array}$} & $\begin{array}{l}\text { Penilaian wajar dengan } \\
\text { pengecualian yang sudah sesuai }\end{array}$ & 0,783 & \multirow[t]{2}{*}{0,764} \\
\hline & & Dapat dipertanggung jawabkan & 0,7884 & \\
\hline \multirow[t]{2}{*}{3.} & \multirow[t]{2}{*}{ Tidak wajar } & $\begin{array}{l}\text { Penilaian wajar yang sesuai dan } \\
\text { dapat dipertanggung jawabkan }\end{array}$ & 0,892 & \multirow[t]{2}{*}{0,888} \\
\hline & & Kesesuaian dengan kode etik & 0,842 & \\
\hline \multirow[t]{2}{*}{4.} & \multirow{2}{*}{$\begin{array}{l}\text { Tidak memberikan } \\
\text { opini }\end{array}$} & $\begin{array}{l}\text { Kesesuaian penilaian tidak } \\
\text { memberi opini }\end{array}$ & 0,754 & \multirow[t]{2}{*}{0,863} \\
\hline & & Opini didasarkan objektivitas & 0,788 & \\
\hline
\end{tabular}

Sumber: Data diolah, 2020 
Tabel 4. Instrumen Tanggung jawab Profesi, Kepentingan Publik, dan Kerahasiaan)

\begin{tabular}{|c|c|c|c|c|}
\hline Sub Variabel & Dimensi & Indikator & Validitas & Reliabilitas \\
\hline \multirow{8}{*}{$\begin{array}{l}\text { Tanggung } \\
\text { jawab Profesi }\end{array}$} & \multirow{2}{*}{$\begin{array}{l}\text { Pertimbangan } \\
\text { moral }\end{array}$} & Pertimbangan moral & 0,887 & \multirow[t]{2}{*}{0,833} \\
\hline & & Tanggung jawab pekerjaan & 0,788 & \\
\hline & \multirow{2}{*}{$\begin{array}{l}\text { Peran penting } \\
\text { dalam masyarakat }\end{array}$} & Berpedoman pada kode etik & 0,982 & \multirow[t]{2}{*}{0,815} \\
\hline & & $\begin{array}{l}\text { Tanggung jawab pendapat } \\
\text { yang dikeluarkan }\end{array}$ & 0,873 & \\
\hline & \multirow{2}{*}{$\begin{array}{l}\text { Berpedoman pada } \\
\text { kode etik }\end{array}$} & Objektivitas & 0,877 & \multirow[t]{2}{*}{0,862} \\
\hline & & Kompetensi profesi & 0,876 & \\
\hline & \multirow[t]{2}{*}{ Tanggung jawab } & $\begin{array}{l}\text { Pengetahuan dan } \\
\text { keterampilan }\end{array}$ & 0,823 & \multirow[t]{2}{*}{0,781} \\
\hline & & Kemampuan bahasa dan TI & 0,775 & \\
\hline \multirow{8}{*}{$\begin{array}{l}\text { Kepentingan } \\
\text { publik }\end{array}$} & \multirow{2}{*}{$\begin{array}{l}\text { Pelayanan } \\
\text { berkualitas }\end{array}$} & Pelayanan berkualitas & 0,798 & \multirow[t]{2}{*}{0,777} \\
\hline & & $\begin{array}{l}\text { Mengikuti standar profesi } \\
\text { akuntan }\end{array}$ & 0,899 & \\
\hline & \multirow{2}{*}{$\begin{array}{l}\text { Berlandaskan } \\
\text { standar profesi }\end{array}$} & Dedikasi & 0,783 & \multirow[t]{2}{*}{0,764} \\
\hline & & Kepentingan publik & 0,763 & \\
\hline & \multirow[t]{2}{*}{ Dedikasi profesi } & Bekerja tepat waktu & 0,754 & \multirow[t]{2}{*}{0,863} \\
\hline & & $\begin{array}{l}\text { Menghormati kepercayaan } \\
\text { yang diberikan }\end{array}$ & 0,788 & \\
\hline & \multirow[t]{2}{*}{$\begin{array}{l}\text { Profesionalisme } \\
\text { dan komitmen }\end{array}$} & $\begin{array}{l}\text { Menunjukkan sikap } \\
\text { profesional }\end{array}$ & 0,892 & \multirow[t]{2}{*}{0,888} \\
\hline & & $\begin{array}{l}\text { Menunjukkan komitmen } \\
\text { bekerja }\end{array}$ & 0,842 & \\
\hline \multirow[t]{8}{*}{ Kerahasiaan } & \multirow{2}{*}{$\begin{array}{l}\text { Menghormati } \\
\text { kerahasiaan }\end{array}$} & Kerahasiaan informasi & 0,877 & \multirow[t]{2}{*}{0,832} \\
\hline & & Rahasia perusahaan & 0,843 & \\
\hline & \multirow[t]{2}{*}{ Independen } & Kertas kerja audit & 0,891 & \multirow[t]{2}{*}{0,831} \\
\hline & & Menjaga staf & 0,891 & \\
\hline & \multirow[t]{2}{*}{ Kerja keras } & Memelihara hubungan baik & 0,824 & \multirow[t]{2}{*}{0,891} \\
\hline & & Menghormati kerahasiaan & 0,867 & \\
\hline & \multirow[t]{2}{*}{ Rahasis klien } & $\begin{array}{l}\text { Menjaga kerahasiaan data } \\
\text { klien }\end{array}$ & 0,874 & \multirow[t]{2}{*}{0,834} \\
\hline & & $\begin{array}{l}\text { Penghayatan kode etik dan } \\
\text { kerahasiaan }\end{array}$ & 0,834 & \\
\hline
\end{tabular}

Sumber: Data diolah, 2020

Tabel 5. Hasil pengujian Normalitas

\begin{tabular}{|l|c|c|c|}
\hline \multicolumn{1}{|c|}{ Variabel } & $\mathbf{Z}_{\text {hitung }}$ & Sig & Keterangan \\
\hline Tanggung jawab Profesi & 1,061 & 0,211 & Normal \\
\hline Kepentingan publik & 0,990 & 0,281 & Normal \\
\hline Kerahasiaan & 1,131 & 0,155 & Normal \\
\hline Opini Akuntan Publik & 0,849 & 0,468 & Normal \\
\hline
\end{tabular}

Sumber: Data diolah, 2020 


\section{Pengujian Validitas dan Reliabilitas Instrumen}

Uji validitas instrument dimaksudkan untuk memastikan apakah data atau instrumen yang digunakan mampu mengukur fenomena dengan baik. Dalam penelitian ini, pengujian validitas dengan membandingkan besarnya nilai $r$ hitung yaitu nilai corrected item-total correlation (CITC) dengan nilai $r$ tabel. Besarnya nilai $r$ tabel diketahui dari df (degree of freedom) tertentu berdasarkan $\mathrm{n}$ sampel. Kriteria pengujiannya, yaitu apabila nilai $r$ hitung $>$ nilai $r$ tabel, maka butir pertanyaan yang disusun dan diajukan kepada responden dinyatakan valid. Sebaliknya, jika r-hitung < r-tabel, maka butir atau variabel dinyatakan tidak valid. Dari Tabel 3 dan Tabel 4 diketahui bahwa hasil pengujian validitas menunjukkan bahwa seluruh instrument yang disusun telah memenuhi asumsi validitas $(>0,5)$.

Selain pengujian validitas, diperlukan uji reliabilitas instrument. Pengujian reliabilitas data atau instrumen terhadap kuesioner penelitian yang digunakan dimaksudkan guna mengetahui apakah secara statistik kuesioner yang digunakan dari masing-masing variabel yang diteliti dinyatakan reliabel atau handal. Kriteria pengujian, yaitu apabila nilai r-Alpha $>$ r-hitung maka dinyatkan reliabel, sebaliknya jika nilai r-Alpha hitung lebih kecil dari r-tabel maka data atau instrumen dinyatakan tidak reliabel. Menurut Sunyoto (2007), menyatakan: suatu kontruk atau variabel dikatakan reliabel jika memberikan nilai Cronbach Alpha $>0,60$. Dari Tabel 4 dan Tabel 4 diketahui bahwa seluruh instrument yang disusun dapat mengukur fenomena secara konsiste yang ditunjukkan oleh nilai alpha Cronbach $>0,6$.

\section{Pengujian Asumasi Klasik}

Pengujian asumsi klasik yang digunakan dalam penelitian ini yaitu uji normalitas data yang dilaksanakan untuk mengetahui penyebaran data, sehingga diketahui apakah sebaran data berdistribusi normal atau tidak. Pengujian normalitas dalam penelitian ini yaitu data dengan menggunakan model uji Kolmogorov-Smirnov (K-S atau D-hitung). Sujarweni (2019), menjelaskan kriteria dari pengujian normalitas data dengan KS test, yaitu jika nilai K-S hitung atau $\mathrm{D} \neg$ hitung lebih besar dari K-S tabel atau D-tabel, maka data dinyatakan berdistribusi normal; dan jika nilai K-S hitung lebih kecil dari nilai K-S tabel maka data tersebut tidak berdistribusi normal. Dari tabel 5 diketahui bahwa seluruh variabel menunjukkan distribusi normal, sehingga dapat diteruskan untuk pengujian hipotesis.

\section{HASIL DAN PEMBAHASAN}

Hasil

Pada dasarnya penelitian ini menganalisi mengenai persepsi terhadap Kode etik akuntan Indonesia oleh Akuntan Publik dan Non Publik. Dimana reponden dari penelitain ini untuk Akuntan Publik di wakiki olek para auditor yang bekerja di Kantor Akuntan Publik (KAP) dan untuk Non Publik diwakili oleh Dosen yang bekerja pada Program Pasca Sarjana Magister Akuntansi di Perguruan Tinggi Swasta di wilayah jakarta yang relatif besar.

Adapun pemilihan responden akuntan publik diambil dari KAP Persekutuan dengan jumlah Akuntan Publik lebih dari 10 (Sepuluh) orang. Sedangkan untuk Akuntan Non Publik Penulis memilih profesi Dosen untuk kampus yang memiliki program studi Magister akuntansi.

Data statistik untuk menghitung frekuensi menggunakan Demografi Identitas Responden untuk mendekripsikan penelitian ini atas jenis kelamin, umur dan lama kerja dari responden.

Persepsi masing-masing Akuntan Publik dan Non Publik berdasarkan demografi responden, hasil perhitungan frekuensi dilihat dari tabel 7. 
Tabel 6. Ringkasan Demografi Identitas Responden

\begin{tabular}{|c|c|c|}
\hline KETERANGAN & KAP & NON KAP \\
\hline Jenis Kelamin & & \\
\hline 1. Laki-laki & $12(21,80 \%)$ & $16(29,10 \%)$ \\
\hline 2. Perempuan & $43(78,20 \%)$ & $39(70,90 \%)$ \\
\hline Umur & & 0 \\
\hline 1. $21-30$ tahun & $48(87,30 \%)$ & 0 \\
\hline 2. 31-40 tahun & $(10,90 \%)$ & $28(50,90 \%)$ \\
\hline 3. 41-50 tahun & 0 & $27(49,10 \%)$ \\
\hline 4. 51-60 tahun & $1(1,80 \%)$ & 0 \\
\hline Lama Kerja & & $1(1,80 \%)$ \\
\hline 1. 1-5 tahun & $47(85,50 \%)$ & $15(27,30 \%)$ \\
\hline 2. 6-10 tahun $11-15$ tahun & $5(9,10 \%)$ & $24(43,60 \%)$ \\
\hline 4. 16-20 tahun & $1(1,80 \%)$ & $15(27,30 \%)$ \\
\hline 5. $21-25$ tahun & $1(1,80 \%)$ & $1(1,80 \%)$ \\
\hline
\end{tabular}

Sumber: Data diolah, 2020

Tabel 7. Nilai Mean Persepsi Akuntan Publik dan Non Publik

\begin{tabular}{|c|l|c|c|c|}
\hline \multirow{2}{*}{ No } & \multirow{2}{*}{ Identitas } & \multicolumn{2}{|c|}{ Nilai Mean } & \multirow{2}{*}{ Keterangan } \\
\cline { 3 - 4 } & & KAP & Non KAP & \\
\hline 1 & Jenis Kelamin & 1,78 & 1,71 & Tidak berbeda \\
\hline 2 & Umur & 1,16 & 3,49 & Berbeda \\
\hline 3 & Lama Kerja & 1,25 & 3,96 & Berbeda \\
\hline
\end{tabular}

Sumber: Data diolah, 2020

Pada tabel 7 tersebut, dapat diketahui bahwa nilai rata-rata (mean) untuk persepsi masing-masing kelompok Akuntan Publik dan Non Publik berdasarkan identitas jenis kelamin, umur dan lama kerja diperoleh hasil, yang dijelaskan sebagai berikut. Jenis kelamin kedua kelompok Akuntan Publik dan Non Publik memilik nilai mean yang hampir sama atau tidak berbeda secara signifikan, karena itu jenis kelamin Akuntan Publik dan Non Publik tidak memiliki perbedaan yang berarti. Apabila dilihat dari kelompok umur antara Akuntan Publik dan Non Publik, keduanya memiliki nilai mean yang berbeda jauh yaitu $1,76<3,49$ sehingga dapat diketahui bahwa dilihat dari umur persepsi kedua akuntan publik memiliki persepsi yang berbeda terhadap Kode Etik
Akuntan Publik Indonesia. Jika dilihat dari kelompok lama kerja, kedua Akuntan Publik dan Non Publik memiliki nilai mean yaitu 1,25 $<3,96$ sehingga dapat diketahui bahwa kelompok Akuntan Publik dan Non Publik memiliki persepsi yang berbeda terhadap Kode Etik Akuntan Publik Indonesia.

\section{Pengujian Hipotesis}

Dari hasil pengujian hipotesis diketahui bahwa rata-rata nilai dari Variabel Tanggungjawab Profesi menunjukkan nilai 37,6 (KAP) dan 39 (Non KAP); Variabel Kepentingan Publik 35 (KAP) dan 32,9 (Non KAP); Variabel Kerahasiaan 32,5 (KAP) dan 36,6 (Non KAP); dan Opini sebesar 33,8 (KAP) dan 37,1 (Non KAP). 
Tabel 8. Hasil pengujian hipotesis

\begin{tabular}{|l|c|c|c|c|}
\hline \multirow{2}{*}{ Variabel } & \multicolumn{2}{c|}{ Mean } & \multirow{2}{*}{$\begin{array}{c}\text { Sig two } \\
\text { tailed }\end{array}$} & Keterangan \\
\cline { 2 - 3 } & KAP & Non KAP & 0,040 & Berbeda \\
\hline Tanggung jawab Profesi & 37,6 & 39,0 & 0,037 & Berbeda \\
\hline Kepentingan publik & 35 & 32,9 & 0,037 & Berbeda \\
\hline Kerahasiaan & 32,5 & 36,6 & 0,003 & Berbeda \\
\hline Opini Akuntan Publik & 33,8 & 37,1 & $0,036 ß$ & \\
\hline
\end{tabular}

Sumber: Data diolah, 2020

Dari hasil pengujian hipotesis pada tabel 8 menunjukkan menyatakan hasil: terdapat perbedaan persepsi antara Akuntan Publik dan Akuntan Non Publik terhadap Kode Etik Akuntan Indonesia dimana nilai dari hasil hasil test independent yang ditunjukkan oleh nilai sig (two tailed) yang lebih kecil dari 0,05.

\section{Pembahasan}

Dengan melihat hasil hipotesis yang telah diuraikan di atas antara akuntan publik dengan akuntan non publik dimana formulasi hipotesis penelitian berbunyi:

"Terdapat perbedaan persepsi antara akuntan publik dengan akuntan non publik terhadap kode etik akuntan Indonesia."

Hasil uji hipotesis kedua terdapat perbedaan persepsi antara Akuntan Publik dan Akuntan Non Publik. Walaupun lebih sedikit dilihat dari mean kedua kelompok tersebut diketahui bahwa persepsi Akuntan Publik (KAP) sebesar memiliki persepsi lebih sedikit dibandingkan dengan Akuntan Non Publik dengan nilai mean lebih tinggi sedikit.

Hal ini disebabkan karena Akuntan Non Publik yang berprofesi sebagai Dosen Magister Akuntansi lebih banyak memiliki pengalaman yang lebih lama dilihat dari lama kerjanya dan juga dapat dilihat secara umur yang relatif lebih matang, sedangkan responden Akuntan Publik yang bekerja sebagai auditor di Kantor Akuntan Publik dengan usia relatif lebih muda dengan lama kerja yang relatif lebih sedikit dibandingkan dengan Akuntan Non Publik.
Sedangkan dari hasil perhitungan pengujian hipotesis yang telah dilakukan dengan menggunakan alat analisis statistik independent sampel t-test yang telah dibahas diatas sebelumnya dapat dilihat dari hasil uji yang dilakukan terdapat perbedaan persepsi positif antara Akuntan Publik dengan Akuntan Non Publik terhadap Kode Etik Ikatan Akuntan Indonesia dilihat dari hasil t-test yang dilakukan hal ini menunjukkan nilai positif dengan hasil t-test 61,665. Bahwa dari hasil reponden akuntan publik dan non publik yang telah menjadi responden memiliki penghayatan dan penafsiran serta pemahaman yang baik terhadap Kode Etik Akuntan Indonesia.

Dalam hal telah diuraikan sebelumnya dalam perhitungan statistik yang dilakukan atas demografi identitas reponden yang dapat dilihat bahwa pada tebel sebelumnya dari jenis kelamin, usia, lama kerja serta pendidikan yang dimiliki oleh reponden sangat cukup memadai untuk dapat memahami Kode Etik Ikatan Akuntan Indonesia karena selain dengan pendidikan formal yang menunjang para reponden juga rata-rata telah mengikuti banyak pelatihan-pelatihan yang cukup untuk mendukung profesi kerja sehingga para responden secara profesionalitas kerja sudah cukup memadai. Dan secara pengalaman kerja yang cukup matang para responden cakap dalam profesinya sehingga mempermudah untuk pemahaman persepsi akan Kode Etik Ikatan Akuntan Indonesia. 


\section{KESIMPULAN DAN SARAN}

Kesimpulan

Berdasarkan uraian analisis dan pengujian hipotesis yang telah dilakukan dengan menggunakan alat analisis statistik independent sampel t-test yang telah dibahas pada bab sebelumnya, maka disimpulkan sebagai berikut. Dari hasil uji yang dilakukan terdapat perbedaan persepsi positif antara Akuntan Publik dengan Akuntan Non Publik terhadap Kode Etik Ikatan Akuntan Indonesia dilihat dari hasil t-test yang dilakukan hal ini menunjukkan bahwa dari hasil reponden akuntan publik dan non publik yang telah menjadi responden memiliki penghayatan dan penafsiran serta pemahaman yang baik terhadap Kode Etik Akuntan Indonesia.

Berdasarkan hasil uji hipotesis tidak terdapat perbedaan persepsi antara Akuntan Publik dan Akuntan Non Publik. Karena hanya 8,6 selisih antara perbedaan kedua kelompok tersebut dilihat dari mean kedua kelompok tersebut diketahui bahwa persepsi Akuntan Publik (KAP) sebesar 110,78 memiliki persepsi lebih sedikit dibandingkan dengan Akuntan Non Publik dengan nilai mean lebih tinggi sedikit sebesar 119,38. Hal ini disebabkan karena Akuntan Non Publik yang berprofesi sebagai Dosen Magister Akuntansi lebih banyak memiliki pengalaman yang lebih lama dilihat dari lama kerjanya dan juga dapat dilihat secara umur yang relatif lebih matang yang dapat dilihat pada pembahasan yang telah diuraikan sebelumnya, sedangkan responden Akuntan Publik yang bekerja sebagai auditor di Kantor Akuntan Publik dengan usia relatif lebih muda dengan lama kerja yang relatif lebih sedikit dibandingkan dengan Akuntan Non Publik.

Dari hasil penelitian ini dapat menjadi masukan dalam masalah kode etik untuk penyempurnaan serta pelaksanaan Kode Etik Akuntan Indonesia bagi para akuntan untuk lebih meningkatkan pengetahuan, menambah pengalaman serta malakukan tugas profesionalnya dengan baik. Hal tersebut dilakukan untuk meningkatkan kepercayaan masyarakat terhadap profesi akuntan di masa yang akan datang.

\section{Saran}

Penelitaian ini memiliki beberapa kelemahan yang membatasi kesempunaan hasil penelitian ini. Untuk itu keterbatasan ini semoga dapat disempurnakan pada penelitian-penelitaian selanjutnya. Pertama adalah Objek penelitian ini adalah auditor yang bekerja pada Kantor Akuntan Publik dan Dosen pada Perguruan Tinggi Swasta yang relatif 5 (Lima) besar di wilayah Jakarta. Dalam hal ini keterbatasan terletak pada profesi akuntan lain yang belum dapat diperoleh persepsi mereka, sehingga akan memungkinkan penilaian persepsi yang berbeda pada kelompok akuntan lain tersebut. Kedua, lingkup penelitian karena keterbatasan biaya dan waktu yang dimiliki peneliti dalam melakukan penelitaian ini hanya dilakukan di kota Jakarta yang meyebabkan kelemahan dalam memilih variasi sampel dengan kondisi lingkungan yang berbeda. Ketiga metode pengumpulan data yang hanya menggunakan metode kuestioner, menyebabkan kurangnya komunikasi langsung dengan subyek penelitain. Selain itu metode kuestioner yang mengandalkan self report akan memberikan kelemahan apabila dijawab dengan tidak jujur.

Dari keterbatasan tersebut penelitian di masa masa mendatang diharapkan mampu memberikan perbaikan diantaranya adalah, pertama menggunakan metode pengumpulan data selain metode survey dengan kuestioner sebaiknya menggunakan metode lain misalnya interview yang dapat digunakan juga untuk memperbaiki komunikasi dua arah dengan subyek dan mendapatkan 
kejujuran jawaban subyek. Kedua, pengembangan kuestioner yang disesuaikan dengan kondisi dan penulisan kata-kata yang mudah dipahami oleh responden untuk dapat digunakan dalam penelitian selanjutnya. Ketiga, penelitian selanjutnya hendaknya memperluas instrumen penelitian karena kode etik akuntan tidak hanya menyangkut prinsip etika saja tetapi meliputi aturan etika dan interpretasi aturan etika. Keempat, penelitian selanjutnya diharapkan dapat menambah objek penelitian dengan secara khusus pada profesi akuntan lainnya misalnya akuntan perusahaan dan akuntan pemerintahan.

Pada penelitian selanjutnya supaya penelitian menjadi lebih baik lagi, sebaiknya dilakukan penelitian dengan memperbesar area survey yang tidak hanya dilakukan di wilayah Jakarta saja tetapi seluruh wilayah Indonesia, agar mewakili polulasi yang menyeluruh.

\section{DAFTAR PUSTAKA}

Arisetyawan, Ronald. 2010. "Analisis

Persepsi Akuntan Publik dan Mahasiswa Pendidikan Profesi Akuntansi Terhadap Kode Etik Ikatan Akuntan Indonesia”. Skripsi Sarjana Fakultas Ekonomi Jurusan Akuntansi. Universitas Diponegoro: Semarang.

Cooper, Donald R., Emory, C. William, Metode Penelitian Bisnis, Jakarta, Gelora Aksara Pratama, 1997.

Ghazali, Imam. 2016. “Aplikasi Multivariat dengan Program IBM SPSS 23". Cetakan kedelapan, Universitas Diponegoro, Semarang.

Gibson dan James, 1993. Organisasi:

Perilaku, Struktur, Proses. Terjemahan NunukAndriani. Jakarta: Binarupa Aksara.

Gibson, J. L., Ivancevich, J. M., \& Donnelly, J. H. (1996). Organisasi, perilaku, struktur dan proses. Bina Rupa Aksara.
Jakarta.

Harjanto, Eko. 2009. "Persepsi Akuntan Pendidik Dan Mahasiswa Akuntansi Terhadap Etika Bisnis Dan Etika Profesi Akuntan". Skripsi Sarjana Fakultas Ekonomi Jurusan Akuntansi Universitas Muhammadiyah, Surakarta.

Indrianto, Nur, Bambang Supomo. 2014. "Metode Penelitian Bisnis Untuk Akuntansi dan Manajemen". BPFE, Yogyakarta.

Isnanto, R. Rizal. 2009. Buku Ajar Etika Profesi. Program Studi Sistem Komputer Fakultas Teknik. Universitas Diponegoro, Semarang.

Juliarta. 2015. Persepsi Mahasiswa Akuntansi dan Akuntan Publik Terhadap Etika Bisnis dan Etika Profesi Akuntan. E-Jurnal. Vol.3 No.1. November 2015.

Keraf, A. Sonny. 1998. Etika Bisnis: Membangun Citra Bisnis sebagai ProfesiLuhur. Yogyakarta: Kanisius.

Lubis, Artan Ikhsan. 2010. Akuntansi Keperilakuan. Edisi 2, Salemba Empat, Jakarta.

Ludigdo, Unti. 2007. Paradoks Etika Akuntan. Pustaka Pelajar, Yogyakarta.

Murtanto dan Marini. 2003. Persepsi Akuntan Pria dan Akuntan Wanita serta Mahasiswa dan Mahasiswi terhadap Etika Bisnis dan Etika Profesi. Simposium Nasional Akuntansi (SNA) VI. Surabaya: 16-17 Oktober.

Nurlan, A. B. (2011). Persepsi Akuntan Dan

Mahasiswa Jurusan Akuntansi Terhadap Kode Etik Ikatan Akuntan Indonesia. Skripsi tidak diterbitkan. Makassar: Fakultas Ekonomi Universitas Hasanuddin.

Regar, Moenaf, H. 2007. Mengenal Profesi Akuntan dan Memahami Laporannya. Cetakan Kedua, PT. Bumi Aksara, Jakarta.

Robbins, Stephen P. dan Timothy A. Judge. 2009, Perilaku Organisasi. Edisi 12. 
Diterjemahkan oleh Diana Angelica, Salemba Emat, Jakarta.

Sartika, D. (2006). Persepsi Dosen Akuntansi

Dan Mahasiswa Akuntansi Terhadap

Kode Etik Akuntan. Skripsi Sarjana

Fakultas Ekonomi Jurusan Akuntansi.

Bengkulu: Universitas Bengkulu.

Soendari, T. (2012). Metode Penelitian

Deskriptif. Bandung, UPI. Stuss,

Magdalena \& Herdan, Agnieszka, 17.

Sunyoto, Danang, 2007, Analisis Regresi dan

Korelasi Bivariat, Ringkasan dan Kasus,

Amara Books, Yogjakarta.

Sujarweni, V. W., \& Utami, L. R. (2019). The master book of SPSS. Anak Hebat Indonesia.

Syva, T. 2020. THE PERCEPTION OF EDUCATOR ACCOUNTANTS \& ACCOUNTING DEPARTMENT STUDENTS TOWARDS THE IKATAN AKUNTAN INDONESIAâ€TM S CODE OF ETHICS. Jurnal Kajian Ilmiah Akuntansi Fakultas Ekonomi UNTAN (KIAFE), 9(2).
Vitriyani, E.N. 2014. Analisis Persepsi Mahasiswa Akuntansi terhadap Etika Profesi Akuntan. Jurnal Universitas Negeri Semarang. ISSN: 2252-6765. Vol. 3 No. 4. Agustus 2014.

Wulansari, Amalia S. 2008. "Studi Persepsi Mahasiswa Akuntansi Terhadap Profesionalisme Dosen Akuntansi Perguruan Tinggi Di Daerah istimewa Yogyakarta”. Universitas Islam Indonesia,Yogyakarta. [A1]

Yen, S. Persepsi Akuntan Publik Dan NonPublik M Kota Medan Terhadap Kode Etik Akentan Indonesia.

Yusriani. (2005). Persepsi Akuntan Pendidik dan kuntan Publik Terhadap Kode Etik Akuntan Indonesia. Semarang. 